Egyptian Journal of Aquatic Biology \& Fisheries

Zoology Department, Faculty of Science,

Ain Shams University, Cairo, Egypt.

ISSN $1110-6131$

Vol. 23(5): 43- 53 (2019)

www.ejabf.journals.ekb.eg

\title{
Polychaetes from Suez Gulf (Gabel EI Zeit), Egypt
}

\author{
Faiza Ali Abdelnaby \\ National Institute of Oceanography and Fishery Alexandria Egypt \\ Faiza_abdelnaby@yahoo.com
}

\begin{abstract}
Article History:
Online: Dec. 2019

Keywords:

Oil pollution

Benthic fauna

Polychaetes

Gulf of Suez

Gable El Zeit

Egypt
\end{abstract}

ARTICLE INFO

Received:Nov.5, 2019

Accepted: Nov.28, 2019

\begin{abstract}
Samples were collected twice Autumn 2018 and Winter 2019, from nine stations were chosen to collect bottom fauna to cover the area of study around sewage pipeline of an oil company in Gable El Zeit, Gulf of Suez. The bottom fauna of the study area consist of 8 taxonomic groups of invertebrate. These groups are Foraminifera, Nematoda, Polychaeta, Bivalvia, Gastropoda, Cumacea, Isopoda and Amphipoda. Due to the importance of macro invertebrate in bio monitoring environmental studies. This study are considered as a step to study bottom fauna present in this area around the sewage Pipeline for an oil company in Gable El Zeit area, as an environmental assessment of this part, with focusing on the polychaete group. The results came out that the stations far away from the drainage pipe are better than nearby also results of some invertebrate groups such as foraminifera, mollusks, polychaetes answer all questions and detected which can used as biomarker of hydrocarbon contamination.
\end{abstract}

\section{INTRODUCTION}

Macrofauna forms the dominant biomass in marine sediment and play an important role in ecosystem processes such as secondary production, nutrient recycling and pollutant metabolism. There are many Oil industries in Suez Gulf, which required great Protection Agency; its control is usually present, Oil considered the most important hydrocarbon contaminant in marine environment (Head et al., 2006). Oil, chemicals and wastes release from Pipelines, due to equipment failure, oil processes, human error or damage. The value of damage depends on where it occurs and how long it remains and impacted environment. Transportation of oil production effect on marine fauna (Dargay and Gately, 2010). Bio monitoring environmental studies used to detect the accumulation of chemicals in marine waters and organisms (Abbes, 2003). Bio monitoring of environment depends on bio indicators species or groups used to determine the presence or absent of contaminants (Chase et al., 2013). Polychaetes show remarkable abundance, species richness and functional diversity in marine benthic communities of both soft and hard bottoms (Musco, 2012). They play key role in ecosystem functioning and in the estimation of diversity and dynamics of benthic communities (Papageorgiou et al., 2006), used as biomarkers due to its capability to accumulate chemicals and hydrocarbons (Mouneyrac et al., 2010, Lucan-Bouché,1999).

Assessing environmental health, as a biological criterion for water quality and in biomonitoring studies (Mikac et al., 2011). They important for the stability of 
communities of bottom fauna (Fauchald, 1977), Many studies in Suez Gulf reported by Por (1978); Safriel \& Lipkin (1975); Ben-Eliahu (1972), Amoureux and Fishelson (1978), El-Komi (1997) and El-Komi \& Beltagy (1997), El Komi and Emara (2008), El-Komi et al., (2002) studied the distribution of the macro benthos assemblages in the shallow intertidal zone along the western coast of the Gulf of Suez, Egypt.

Hargrave and Thiel (1983) mentioned that Contamination by petroleum hydrocarbons from oil spills and oil refineries effect on the biology and physiology of benthic organisms which live on bottom (Massara Paletto et al., 2008). Making loss in diversity, richness and abundance of benthic organisms (Yu et al. 2013; Seo et al., 2014). So this study are considered as a step to study bottom fauna present in this area around the sewage Pipeline for one of oil company in Gable El zaat area, as an environmental assessment of this part, with focusing on the polychaete group.

\section{METHOD AND MATERIAL}

Samples were collected twice Autumn 2018 and Winter 2019, from nine stations were chosen to collect bottom fauna to cover the area around an Oil Company (Gable El Zeit, Gulf of Suez) sewage Pipeline (Fig.1). Samples were collected by using Van Veen grab $(25 \times 25 \mathrm{~cm})$. In the laboratory samples were washed through $0.2 \mathrm{~mm}$ mesh sieve for small polychaetes and $0.5 \mathrm{~mm}$ for the rest of fauna, and then fixed with a $70 \%$ ethyl alcohol solution, materials were sorted under a stereomicroscope, then species identified to species level. The photographs of the some species were taken by a digital camera attached to stereo and compound microscopes. The biological diversity coefficient (Shannon-Fenner) was calculated in different stations by applying the following equation (Deshmukh, 1986):

$\mathrm{H}=-\Sigma(\mathrm{ni} / \mathrm{N}) \ln (\mathrm{ni} / \mathrm{N})$

Also ANOVA test used to detect significant variation between stations, also species abundance was subjected to the cluster analysis for similarity between stations.

\section{RESULTS}

The macrofauna of the study area was represented by 116 species belonging to 8 taxonomic groups of invertebrate (Table1). These groups are Foraminifera, Nematoda, Polychaeta, Bivalvia, Gastropoda, Cumacea, Isopoda and Amphipoda.

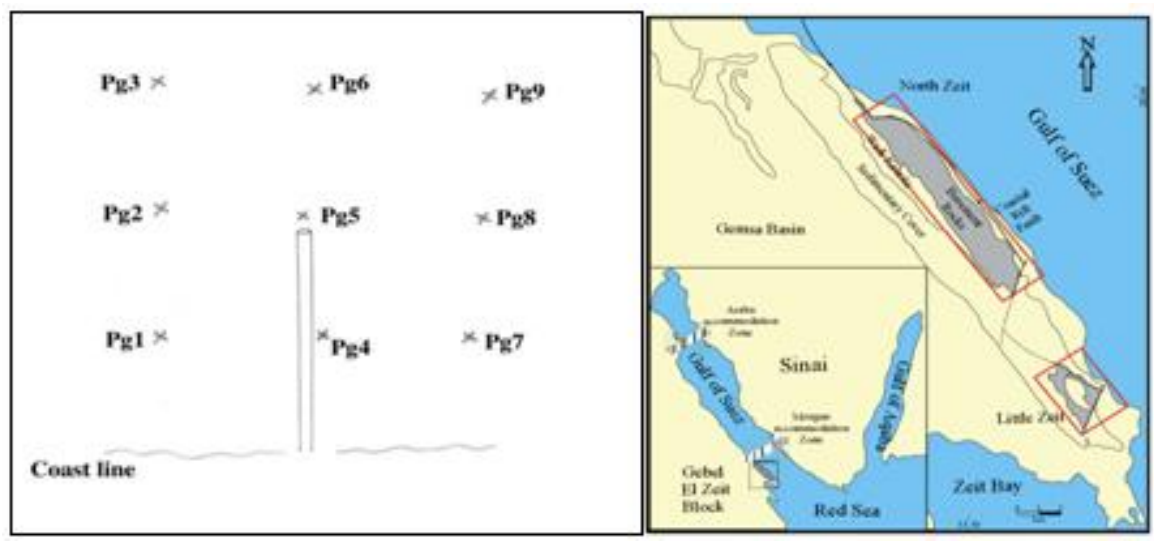

Fig. 1: A general outline of the locations of sampling stations of the bottom fauna of the study area and map of Suez Gulf showing the location of Petro Gulf Company in Gable El Zaat. 
Table 1: Shows the number of ind. $/ \mathrm{m}^{2}$ and number of specie in each site in the study area.

\begin{tabular}{|c|c|c|c|c|c|c|c|c|c|}
\hline Species/ stations & PG1 & PG2 & PG3 & PG4 & PG5 & PG6 & PG7 & PG8 & PG9 \\
\hline Nematoda spp. & 560 & 288 & 512 & 80 & 1856 & 304 & 256 & 624 & 64 \\
\hline Polychates & 0 & 0 & 0 & 0 & 0 & 0 & 0 & 0 & 0 \\
\hline Aglaophamus dibranchis (Grube, 1877) & 0 & 16 & 0 & 0 & 0 & 16 & 0 & 16 & 16 \\
\hline Aglaophamus lyrochaeta (Fauvel, 1902) & 0 & 16 & 0 & 0 & 0 & 0 & 0 & 0 & 0 \\
\hline Amphicteis gunneri (M. Sars, 1835) & 32 & 0 & 0 & 0 & 0 & 0 & 0 & 0 & 0 \\
\hline Ampharete acutifrons (Grube, 1860) & 0 & 0 & 0 & 0 & 0 & 16 & 0 & 16 & 272 \\
\hline Aonides oxycephala (Sars, 1862) & 0 & 32 & 0 & 0 & 32 & 32 & 0 & 0 & 32 \\
\hline Arichlidon reyssi (Katzmann, Laubier \& Ramos, 1974) & 0 & 0 & 0 & 0 & 0 & 0 & 0 & 0 & 16 \\
\hline $\begin{array}{l}\text { Arichlidon watsonae Cruz-Gómez \& Bastida-Zavala, } \\
2018\end{array}$ & 0 & 0 & 0 & 0 & 32 & 0 & 0 & 0 & 16 \\
\hline Aricidea (Acmira) cerrutii Laubier, 1966 & 16 & 0 & 0 & 0 & 0 & 32 & 0 & 16 & 16 \\
\hline $\begin{array}{l}\text { Aricidea (Aricidea) capensis bansei Laubier \& Ramos, } \\
1974\end{array}$ & 32 & 48 & 0 & 0 & 0 & 0 & 16 & 0 & 96 \\
\hline Aricidea (Stnelzovia) suecica Eliason, 1920 & 0 & 0 & 0 & 0 & 0 & 0 & 16 & 0 & 32 \\
\hline Armandia casuarina Moreira \& Parapar, 2017 & 32 & 0 & 0 & 0 & 0 & 0 & 0 & 0 & 32 \\
\hline Aphelochaeta filiformis (Keferstein, 1862) & 0 & 32 & 0 & 0 & 0 & 0 & 0 & 0 & 0 \\
\hline Brania furcelligera (Augener, 1913) & 16 & 32 & 0 & 0 & 0 & 0 & 0 & 0 & 48 \\
\hline Capitella capitata (Fabricius, 1780) & 0 & 0 & 16 & 0 & 0 & 0 & 0 & 0 & 0 \\
\hline Ceratonereis mirabilis Kinberg, 1865 & 0 & 32 & 0 & 0 & 0 & 0 & 0 & 0 & 0 \\
\hline Chone filicaudata Southern, 1914 & 32 & 0 & 0 & 0 & 0 & 16 & 0 & 16 & 32 \\
\hline Chrysopetalum occidentale Johnson, 1897. & 0 & 0 & 0 & 0 & 0 & 0 & 32 & 16 & 0 \\
\hline Cirriformia capensis (Schmarda, 1861) & 0 & 32 & 0 & 0 & 0 & 0 & 0 & 0 & 0 \\
\hline Cirriformia tentaculata (Montagu, 1808) & 0 & 0 & 16 & 0 & 0 & 0 & 0 & 16 & 0 \\
\hline Protocirrineris chrysoderma (Claparède, 1868) & 0 & 0 & 0 & 0 & 0 & 0 & 0 & 16 & 0 \\
\hline Cossura longocirrata Webster \& Benedict, 1887. & 0 & 0 & 48 & 0 & 0 & 0 & 0 & 0 & 0 \\
\hline Diopatra neapolitana Delle Chiaje, 1841 & 16 & 0 & 0 & 0 & 0 & 0 & 0 & 0 & 0 \\
\hline Diplocirrus capensis Day, 1961 & 0 & 0 & 0 & 0 & 0 & 0 & 0 & 32 & 16 \\
\hline Euclymene lombricoides (Quatrefages, 1866). & 0 & 16 & 0 & & 0 & 0 & 16 & 0 & 0 \\
\hline Euclymene oerstedii (Claparède, 1863$)$ & 0 & 16 & 0 & 0 & 0 & 16 & 0 & 0 & 0 \\
\hline Euclymene mossambica (Day, 1957) & 0 & 16 & 0 & 0 & 0 & 0 & 0 & 0 & 0 \\
\hline Eunice vittata (Delle Chiaje, 1828) & 16 & 32 & 0 & 0 & 0 & 0 & 0 & 0 & 0 \\
\hline Exogone dispar (Webster, 1879) & 32 & 16 & 0 & 0 & 0 & 0 & 0 & 0 & 16 \\
\hline Exogone homosetosa Hartmann-Schröder, 1965 & 16 & 0 & 0 & 0 & 0 & 0 & 32 & 0 & 0 \\
\hline Exogone simplex Hartmann-Schröder, 1960. & 16 & 0 & 0 & 0 & 0 & 0 & 0 & 0 & 16 \\
\hline Fabricinuda mossambica (Day, 1957). & 0 & 16 & 48 & 48 & 16 & 32 & 0 & 192 & 32 \\
\hline Goniada asiatica Hartman, 1976. & 0 & 16 & 0 & 0 & 0 & 16 & 0 & 0 & 32 \\
\hline Glycera brevicirris Grube, 1870. & 16 & 0 & 0 & 0 & 16 & 0 & 0 & 0 & 0 \\
\hline Glycera sphyrabrancha Schmarda, 1861 & 0 & 0 & 0 & 0 & 0 & 16 & 0 & 0 & 32 \\
\hline Hesionides arenaria Friedrich, 1937. & 0 & 0 & 0 & 0 & 0 & 0 & 16 & 0 & 0 \\
\hline Hesione splendida Lamarck, 1818. & 16 & 0 & 0 & 0 & 0 & 0 & 0 & 0 & 32 \\
\hline Hesionura elongata (Southern, 1914). & 16 & 16 & 16 & 0 & 0 & 0 & 48 & 0 & 0 \\
\hline Heteromastus filiformis (Claparède, 1864). & 0 & 32 & 16 & 0 & 0 & 0 & 0 & 16 & 0 \\
\hline Hydroides elegans (Haswell, 1883). & 0 & 32 & 0 & 0 & 0 & 0 & 0 & 0 & 0 \\
\hline Hypereteone foliosa (Quatrefages, 1865). & 16 & 0 & 0 & 0 & 0 & 0 & 0 & 0 & 0 \\
\hline Hypereteone heteropoda (Hartman, 1951). & 0 & 0 & 0 & 0 & 32 & 0 & 0 & 0 & 0 \\
\hline Hypsicomus capensis Day, 1961. & 32 & 0 & 0 & 0 & 0 & 0 & 0 & 0 & 0 \\
\hline Isolda pulchella Müller in Grube, 1858. & 0 & 0 & 0 & 0 & 0 & 0 & 0 & 32 & 0 \\
\hline Kirkegaardia annulosa (Hartman, 1965) & 0 & 16 & 0 & 0 & 0 & 0 & 0 & 0 & 16 \\
\hline Leiochone tenuis Day, 1957 mald. & 0 & 16 & 0 & 0 & 0 & 0 & 0 & 0 & 0 \\
\hline Lumbrineris cruzensis Hartman, 1944. & 32 & 16 & 0 & 0 & 0 & 0 & 96 & 48 & 96 \\
\hline Lumbrineris latreilli Audouin \& Milne Edwards, 1834 & 16 & 0 & 0 & 0 & 0 & 0 & 16 & 0 & 0 \\
\hline Lumbrineris coccinea (Renier, 1804) & 0 & 0 & 0 & 0 & 0 & 0 & 0 & 32 & 0 \\
\hline Lumbrineriopsis paradoxa (Saint-Joseph, 1888) & 16 & 0 & 0 & 0 & 0 & 0 & 32 & 16 & 0 \\
\hline Magelona mirabilis (Johnston, 1865) & 0 & 0 & 0 & 0 & 0 & 0 & 0 & 0 & 32 \\
\hline Mediomastus fragilis Rasmussen, 1973. & 0 & 0 & 0 & 0 & 0 & 0 & 0 & 0 & 32 \\
\hline $\begin{array}{l}\text { Micronephthys sphaerocirrata (Wesenberg-Lund, } \\
\text { 1949) }\end{array}$ & 0 & 48 & 32 & 0 & 0 & 16 & 0 & 0 & 16 \\
\hline Micronereides capensis Day, 1963. & 0 & 0 & 0 & 0 & 0 & 16 & 0 & 32 & 0 \\
\hline Neanthes acuminata (Ehlers, 1868). & 0 & 0 & 0 & 0 & 0 & 0 & 0 & 16 & 16 \\
\hline Nereimyra punctata (Müller, 1788). & 0 & 0 & 0 & 0 & 0 & 0 & 0 & 0 & 16 \\
\hline Nephtys longosetosa Örsted, 1842 & 0 & 0 & 0 & 0 & 0 & 0 & 0 & 0 & 32 \\
\hline Nephtys paradoxa Malm, 1874. & 32 & 16 & 32 & 0 & 0 & 0 & 0 & 0 & 0 \\
\hline Notomastus latericeus Sars, 1851. & 48 & 32 & 0 & 0 & 0 & 0 & 0 & 32 & 0 \\
\hline Notomastus mossambicus (Thomassin, 1970). & 16 & 0 & 0 & 0 & 0 & 32 & 0 & 0 & 0 \\
\hline Owenia fusiformis Delle Chiaje, 1844 & 0 & 0 & 0 & 0 & 32 & 0 & 0 & 0 & 16 \\
\hline Onuphis eremita oculata Hartman, 1951. & 0 & 0 & 0 & 0 & 0 & 0 & 0 & 0 & 32 \\
\hline Opisthodonta morena Langerhans, 1879 & 16 & 0 & 0 & 0 & 0 & 0 & 0 & 0 & 0 \\
\hline Oxydromus obscurus (Verrill, 1873). & 32 & 0 & 0 & 0 & 0 & 0 & 0 & 0 & 16 \\
\hline
\end{tabular}




\begin{tabular}{|c|c|c|c|c|c|c|c|c|c|}
\hline Paucibranchia conferta (Moore, 1911). & 0 & 0 & 0 & 0 & 0 & 0 & 0 & 0 & 16 \\
\hline Parexogone hebes (Webster \& Benedict, 1884) & 0 & 0 & 16 & 0 & 0 & 0 & 0 & 0 & 0 \\
\hline Pholoe minuta (Fabricius, 1780). & 0 & 0 & 0 & 0 & 0 & 16 & 0 & 16 & 32 \\
\hline Phyllodoce groenlandica Örsted, 1842 & 0 & 32 & 0 & 0 & 0 & 0 & 0 & 0 & 0 \\
\hline $\begin{array}{l}\text { Pionosyllis heterochaetosa San Martín \& Hutchings, } \\
2006 .\end{array}$ & 0 & 0 & 0 & 0 & 16 & 0 & 0 & 0 & 0 \\
\hline Podarkeopsis capensis (Day, 1963) & 0 & 0 & 0 & 0 & 16 & 0 & 0 & 0 & 0 \\
\hline Poecilochaetus spinulosus Mackie, 1990 & 0 & 0 & 0 & 0 & 0 & 0 & 0 & 0 & 32 \\
\hline Prionospio cirrifera Wirén, 1883. & 32 & 0 & 0 & 0 & 0 & 16 & 32 & 48 & 16 \\
\hline Prionospio ehlersi Fauvel, 1928. & 112 & 64 & 32 & 0 & 0 & 16 & 32 & 48 & 48 \\
\hline Prionospio heterobranchia Moore, 1907 & 0 & 0 & 16 & 0 & 16 & 0 & 32 & 16 & 32 \\
\hline Prionospio saccifera Mackie \& Hartley, 1990 & 0 & 16 & 0 & 0 & 16 & 0 & 0 & 0 & 0 \\
\hline Prionospio steenstrupi Malmgren, 1867 & 0 & 0 & 16 & 0 & 0 & 0 & 0 & 0 & 0 \\
\hline Pista unibranchiata Day, 1963 & 0 & 0 & 0 & 0 & 0 & 0 & 0 & 0 & 16 \\
\hline Protocirrineris chrysoderma (Claparède, 1868) & 0 & 0 & 0 & 0 & 0 & 0 & 0 & 0 & 16 \\
\hline $\begin{array}{l}\text { Prosphaerosyllis campoy (San Martín, Acero, } \\
\text { Contonente \& Gomez, 1982) }\end{array}$ & 16 & 0 & 16 & 0 & 0 & 0 & 0 & 0 & 32 \\
\hline Sabella fusca Johnston, 1836 & 16 & 16 & 16 & 0 & 0 & 16 & 32 & 48 & 16 \\
\hline Psamathe fusca Johnston, 1836 & 0 & 16 & 0 & 0 & 0 & 0 & 32 & 32 & 0 \\
\hline Scolelepis (Scolelepis) squamata (O.F. Muller, 1806) & 16 & 0 & 0 & 0 & 0 & 0 & 32 & 16 & 0 \\
\hline Schistomeringos rudolphi (Delle Chiaje, 1828) & 16 & 0 & 0 & 0 & 0 & 0 & 0 & 0 & 0 \\
\hline Sigambra tentaculata $($ Treadwell, 1941) & 0 & 0 & 0 & 0 & 0 & 0 & 0 & 0 & 16 \\
\hline Sige bifoliata (Moore, 1909). & 0 & 16 & 0 & 0 & 0 & 0 & 0 & 16 & 0 \\
\hline $\begin{array}{l}\text { Sphaerosyllis annulata Nogueira, San Martín \& } \\
\text { Fukuda, } 2004\end{array}$ & 0 & 0 & 0 & 0 & 0 & 0 & 0 & 48 & 0 \\
\hline Sphaerosyllis pirifera Claparède, 1868 & 0 & 0 & 32 & 0 & 0 & 0 & 0 & 0 & 0 \\
\hline Sphaerosyllis parabulbosa San Martín \& López, 2002. & 32 & 0 & 0 & 0 & 0 & 0 & 0 & 0 & 32 \\
\hline Sthenelais boa (Johnston, 1833). & 0 & 0 & 0 & 0 & & 0 & 0 & 16 & 0 \\
\hline Streptosyllis aequiseta Hartmann-Schröder, 1981. & 16 & 0 & 32 & 0 & 0 & 16 & 0 & 0 & 32 \\
\hline Streptosyllis bidentata Southern, 1914. & 0 & 0 & 48 & 0 & 0 & 0 & 0 & 0 & 32 \\
\hline Syllis caeca (Katzmann, 1973) & 0 & 0 & 0 & 0 & 0 & 0 & 0 & 32 & 32 \\
\hline Syllis garciai (Campoy, 1982). & 16 & 0 & 48 & 0 & 0 & 0 & 0 & 0 & 48 \\
\hline Timarete punctata (Grube, 1859). & 0 & 0 & 0 & 0 & 0 & 0 & 0 & 16 & 0 \\
\hline Westheidesyllis corallicola (Ding \& Westheide, 1997). & 16 & 0 & 0 & 0 & 0 & 16 & 0 & 16 & 96 \\
\hline Gastropoda & 0 & 0 & 0 & 0 & 0 & 0 & 0 & 0 & 0 \\
\hline Acteocina simplex & 16 & 0 & 0 & 0 & 0 & 0 & 0 & 0 & 0 \\
\hline Laevidentalium sp & 16 & 0 & 0 & 0 & 0 & 0 & 0 & 0 & 0 \\
\hline Viriola corrugata & 0 & 0 & 0 & 16 & 0 & 0 & 0 & 0 & 0 \\
\hline Vexillum sp. & 0 & 16 & 0 & 0 & 0 & 0 & 0 & 0 & 0 \\
\hline Casmaria sp. & 16 & 0 & 0 & 0 & 0 & 0 & 0 & 0 & 0 \\
\hline Bivalvia & 0 & 0 & 0 & 0 & 0 & 0 & 0 & 0 & 0 \\
\hline Moerella lactea & 16 & 0 & 0 & 0 & 0 & 0 & 0 & 0 & 0 \\
\hline Cardium sp. & 16 & 0 & 0 & 0 & 0 & 0 & 0 & 0 & 0 \\
\hline Pseudometis sp. & 0 & 32 & 0 & 0 & 0 & 0 & 0 & 0 & 0 \\
\hline Cardiolucina semperiana & 0 & 0 & 16 & 0 & 0 & 0 & 0 & 32 & 0 \\
\hline Tellidora lamellosa & 0 & 0 & 0 & 0 & 0 & 0 & 0 & 16 & 0 \\
\hline Cumacea & 0 & 0 & 0 & 0 & 0 & 0 & 0 & 0 & 0 \\
\hline Distylis sp & 16 & 0 & 0 & 0 & 0 & 0 & 0 & 0 & 0 \\
\hline Iphinoe sp & 16 & 0 & 0 & 0 & 0 & 0 & 0 & 32 & 0 \\
\hline Isopoda & 0 & 0 & 0 & 0 & 0 & 0 & 0 & 0 & 0 \\
\hline Mesanthura sp & 0 & 16 & 0 & 0 & 0 & 0 & 0 & 0 & 0 \\
\hline Amphipoda & 0 & 0 & 0 & 0 & 0 & 0 & 0 & 0 & 0 \\
\hline Apocorophium sp. & 16 & 0 & 0 & 0 & 0 & 0 & 0 & 0 & 0 \\
\hline Lysianassa sp. & 16 & 0 & 0 & 0 & 0 & 0 & 0 & 16 & 16 \\
\hline Lembos teleporus & 16 & 0 & 0 & 0 & 0 & 0 & 0 & 16 & 0 \\
\hline Amphilochus neapolitanus & 0 & 0 & 0 & 0 & 0 & 0 & 0 & 48 & 0 \\
\hline Ampelisca excavat & 0 & 0 & 32 & 0 & 0 & 0 & 0 & 0 & 16 \\
\hline Leucothoe bannwarthi (Schellenberg, 1928) & 0 & 0 & 0 & 0 & 0 & 0 & 0 & 16 & 0 \\
\hline Erichthonius brasiliensis (Dana). Delagoa Bay & 0 & 0 & 0 & 0 & 0 & 0 & 0 & 32 & 16 \\
\hline Ostracoda sp. & 64 & 0 & 32 & 0 & 64 & 0 & 0 & 0 & 0 \\
\hline Total number of individuals $/ \mathrm{m}^{2}$ & 1632 & 1104 & 1088 & 144 & 2160 & 656 & 768 & 1760 & 1776 \\
\hline Total number of species & 46 & 35 & 21 & 3 & 13 & 19 & 17 & 39 & 51 \\
\hline Diversity index & 2.051 & 2.075 & 1.84 & 0.28 & 0.98 & 1.775 & 1.74 & 2.185 & 3.1 \\
\hline
\end{tabular}

Table one showed the total number of individuals and number of species also the diversity of organisms in each station. There are many types of foraminifera shells with great numbers are recorded in most station but became less in number in station 
number four and five, also great numbers of nematodes are present are counted in all stations, maximum number were recorded in station PG5 (1856 ind./ $\left.\mathrm{m}^{2}\right)$, while less number are present in stations PG4 and PG9 (80, 64 ind./ $/ \mathrm{m}^{2}$ respectively). Mollusks represented by 10 species five Gastropods and five Bivalve (Table1), Cumacea two species Distylis sp. and Iphinoe sp., Isopoda one species Mesanthura sp. recorded in PG2, seven Amphipoda species are represented but with less number of individuals in most station except stations PG8, PG1 and PG9, they are Apocorophium sp, Lysianassa sp, Lembos teleporus, Amphilochus neapolitanus, Ampelisca excavat, Leucothoe bannwarthi, Erichthonius brasiliensis.

Great total number of individuals recorded at station PG5 (2160 ind./ $\left./ \mathrm{m}^{2}\right)$ due to the presence of great number of nematode $\left(1856 \mathrm{ind} . / \mathrm{m}^{2}\right)$, it share by $19 \%$ of the total number of individuals recorded during this study, stations number 4,6 and 7 shared by $1 \%, 6 \%$ and $7 \%$ from the total number of organisms respectively (Fig. 2).

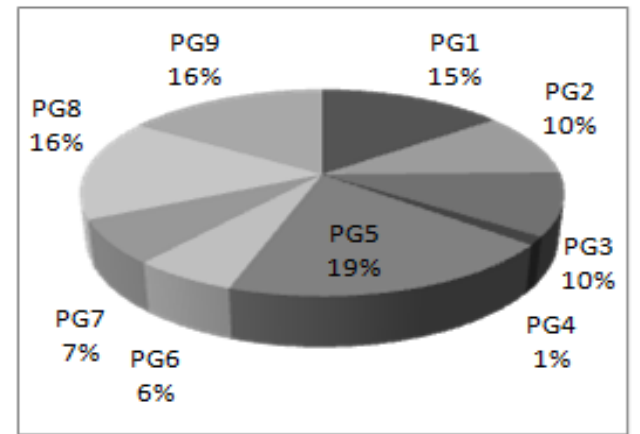

Fig. 2: Shows the percent of total number of individuals of organisms for all fauna in each station at the study area.

Polychaetes was the most diversified group represented by (94 species) belonging to 28 families and 70 genera with total number of individuals 5808 ind. $/ \mathrm{m}^{2}$, average polychaete abundance was high at station PG9 and low at station PG4 ( 48 ind. $\left./ \mathrm{m}^{2}\right)$. ANOVA test showed insignificant variation between stations $(\mathrm{P}<0.05)$ and detected that maximum abundance of polychaetes was at station PG9 (1648 ind./ $\mathrm{m}^{2}$ ) and the least one at station PG4 (48 ind. $\left./ \mathrm{m}^{2}\right)$ (Tables $\left.3 \& 4\right)$. Thirty three polychaete species dominant in the study area, their abundance together contributed $43.251 \%$ from the total polychaetes fauna (Table 2).

Table 2: Dominant polychaete species at sampling station during the present study.

\begin{tabular}{|c|c|c|c|c|c|c|c|c|c|c|}
\hline Dominant polychaete species & PG1 & PG1 & PG1 & PG1 & PG1 & PG1 & PG1 & PG1 & PG1 & $\%$ \\
\hline Fabricinuda mossambica (Day, 1957). & 0 & 16 & 48 & 48 & 16 & 32 & 0 & 192 & 32 & 6.65 \\
\hline $\begin{array}{l}\text { Streptosyllis aequiseta Hartmann-Schröder, } \\
1981 .\end{array}$ & 16 & 0 & 32 & 0 & 0 & 16 & 0 & 0 & 32 & 1.63 \\
\hline Sabella fusca Johnston, 1836 & 16 & 16 & 16 & 0 & 0 & 16 & 32 & 48 & 16 & 2.76 \\
\hline Prionospio ehlersi Fauvel, 1928. & 112 & 64 & 32 & 0 & 0 & 16 & 32 & 48 & 48 & 6.06 \\
\hline Ampharete acutifrons (Grube, 1860) & 0 & 0 & 0 & 0 & 0 & 16 & 0 & 16 & 272 & 5.24 \\
\hline Prionospio cirrifera Wirén, 1883. & 32 & 0 & 0 & 0 & 0 & 16 & 32 & 48 & 16 & 2.47 \\
\hline $\begin{array}{l}\text { Westheidesyllis corallicola (Ding \& } \\
\text { Westheide, 1997). }\end{array}$ & 16 & 0 & 0 & 0 & 0 & 16 & 0 & 16 & 96 & 2.47 \\
\hline Prionospio heterobranchia Moore, 1907 & 0 & 0 & 16 & 0 & 16 & 0 & 32 & 16 & 32 & 1.91 \\
\hline $\begin{array}{l}\text { Micronephthys sphaerocirrata (Wesenberg- } \\
\text { Lund, 1949) }\end{array}$ & 0 & 48 & 32 & 0 & 0 & 16 & 0 & 0 & 16 & 1.91 \\
\hline $\begin{array}{l}\text { Aricidea (Aricidea) capensis bansei Laubier } \\
\& \text { Ramos, } 1974\end{array}$ & 32 & 48 & 0 & 0 & 0 & 0 & 16 & 0 & 96 & 3.31 \\
\hline Aonides oxycephala (Sars, 1862) & & 32 & 0 & 0 & 32 & 32 & 0 & 0 & 32 & 2.20 \\
\hline Lumbrineris cruzensis Hartman, 1944. & 32 & 16 & 0 & 0 & 0 & 0 & 96 & 48 & 96 & 4.96 \\
\hline Hesionura elongata (Southern, 1914). & 16 & 16 & 16 & 0 & 0 & 0 & 48 & 0 & 0 & 1.63 \\
\hline
\end{tabular}

Table 3: Analysis of Variance (ANOVA)

\begin{tabular}{llllll}
\hline Source & DF & Adj SS & Adj MS & F-Value & P-Value \\
\hline Factor & 8 & 18928 & 2366.0 & 8.19 & 0.000 \\
Error & 846 & 244467 & 289.0 & &
\end{tabular}


Table 4: Represented the means

\begin{tabular}{lllll}
\hline Factor & $\mathrm{N}$ & Mean & StDev & $95 \%$ CI \\
\hline PG1 & 95 & 8.93 & 15.95 & $(5.50 ; 12.35)$ \\
PG2 & 95 & 7.92 & 13.58 & $(4.49 ; 11.34)$ \\
PG3 & 95 & 5.22 & 12.23 & $(1.80 ; 8.64)$ \\
PG4 & 95 & 0.505 & 4.925 & $(-2.918 ; 3.928)$ \\
PG5 & 95 & 2.358 & 7.369 & $(-1.065 ; 5.781)$ \\
PG6 & 95 & 3.705 & 8.236 & $(0.282 ; 7.128)$ \\
PG7 & 95 & 5.39 & 14.31 & $(1.97 ; 8.81)$ \\
PG8 & 95 & 9.77 & 23.26 & $(6.35 ; 13.19)$ \\
PG9 & 95 & 17.35 & 33.47 & $(13.92 ; 20.77)$ \\
\hline
\end{tabular}

The average abundance of Fabricinuda mossambica range (16-192 ind. $\left./ \mathrm{m}^{2}\right)$, Prionospio ehlersi range (16-112 ind./ $\left./ \mathrm{m}^{2}\right)$ and Ampharete acutifrons range (16-272 ind. $\left./ \mathrm{m}^{2}\right)$ species. This study revealed that family Spionidae (7 species) and Syllidae (16 species) with the highest number of individuals (848 and 978 ind. $/ \mathrm{m}^{2}$ respectively), shared by $14 \%$ and $17 \%$, followed by family Sabellidae shared by $12 \%$ from the total polychaetes individuals and the rest families with less percent (Fig.7). Polychaetes are representative in all stations, with an average $81 \%$ of the total number of species and $53 \%$ from the total number of individuals followed by nematode, which represented by $41 \%$ from the total number of individuals of total fauna. While the rest of groups showed less percent (Figs. 3, 4).

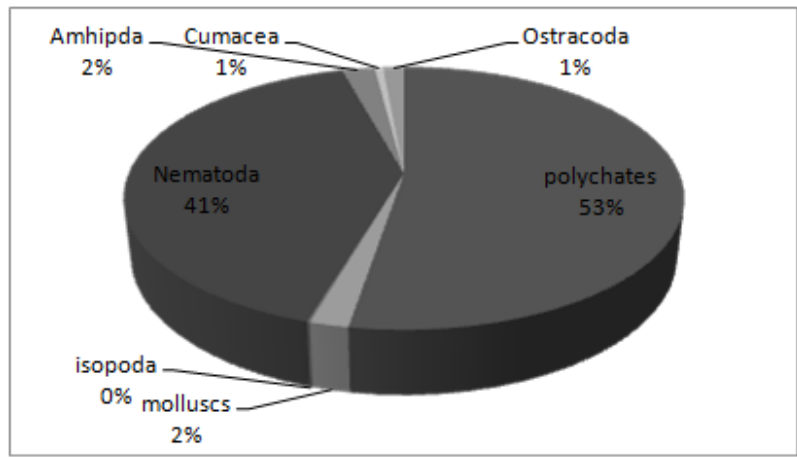

Fig. 3: Shows the percent of total number of individuals for each group of fauna in the study area.

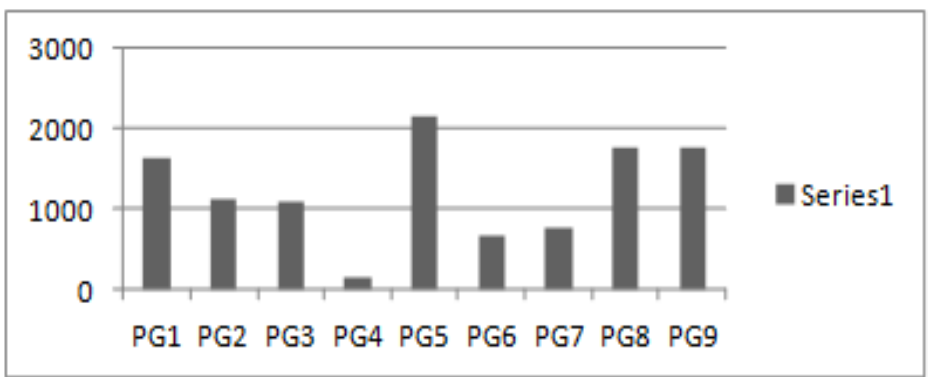

Fig. 4: Shows the total number of inds. $/ \mathrm{m}^{2}$ in each station at the area of study.

Stations PG9 are the most diverse station (51 species), also 46 species recorded at station PG1. PG4 with the least number of species ( 3 species).

Table (1), Fig. (5). indicates an increase in the number of species in the areas fare from the source of drainage. 


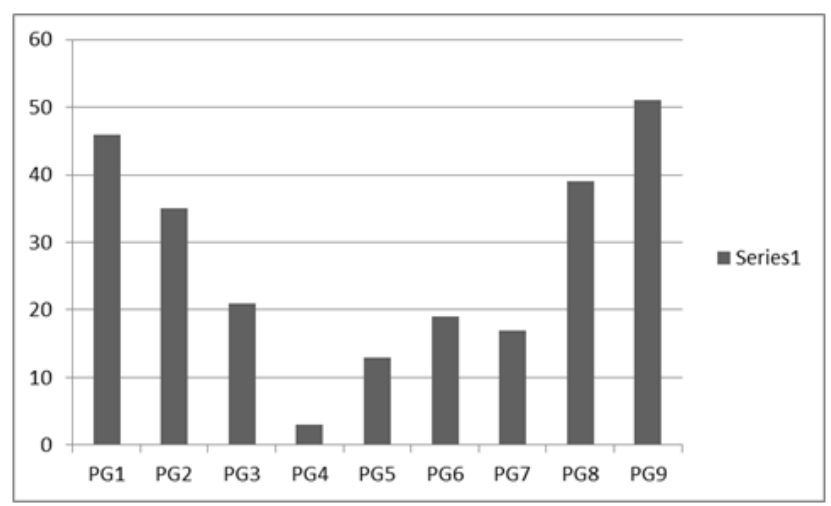

Fig. 5: Shows the total number of species in each station at the area of study.

The biological diversity coefficient (Shannon-Fennier) was calculated in different stations by applying the following equation (Deshmukh, 1986):

$\mathrm{H}=-\Sigma(\mathrm{ni} / \mathrm{N}) \ln (\mathrm{ni} / \mathrm{N})$

Where ni represents the number of species in each station, while $\mathrm{N}$ is the total number of all species in the same station. This coefficient indicates the degree of pollution in different stations and decreases its value as pollution increases.

The results showed that the highest values of the biological diversity parameters (3.1 and 2.185) are recorded in the stations PG9 and PG8 respectively. A relatively large value (2.05 and 2.075) also recorded in PG1and PG2 stations respectively while the lowest value was (0.28 and 0.98) are recorded in stations (PG4 and PG5), (Fig. 6).

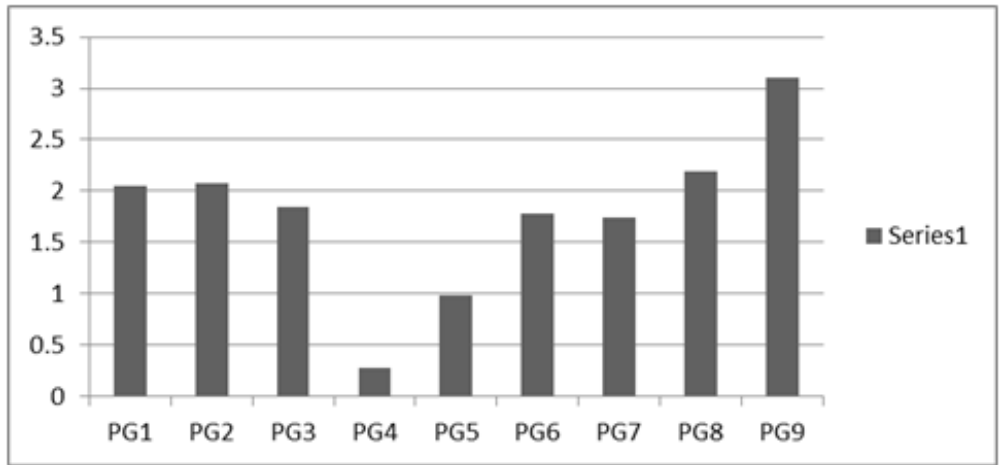

Fig. 6: Shows the biological diversity of each station of the study area.

The degree of contamination of water bodies was classified according to the value of biological diversity factor (Wiehm, 1972). It is assumed that the higher value of 3 indicates that this area is free of pollutants and that the value between 1 and 3 indicates that this area has a moderate percentage of pollution. A value of less than 1 indicates that this area has a high percentage of contaminants.

If this assumption is taken stations PG2 and PG9 are fare from the sources of pollutants. Station PG4 is the most polluted and has a high percentage of contaminants with a biodiversity value of 0.28 . The lowest percentage of pollution is assumed to be located at stations PG2 and PG9 (Figure 6). So, these stations can be taken as references. 


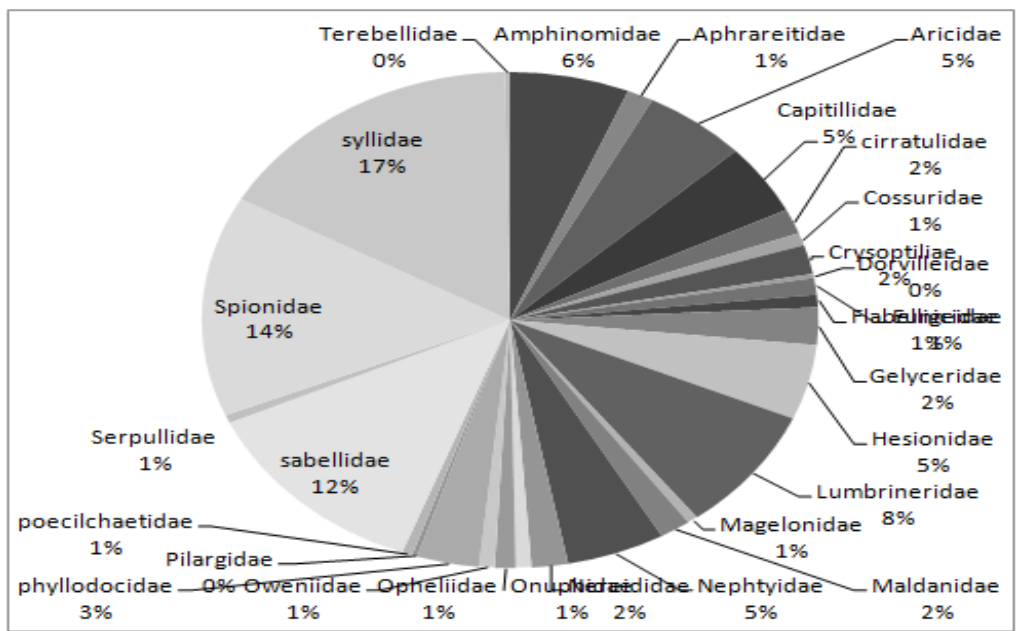

Fig. 7: Shows the percent of each family of polychaetes recorded in the study area.

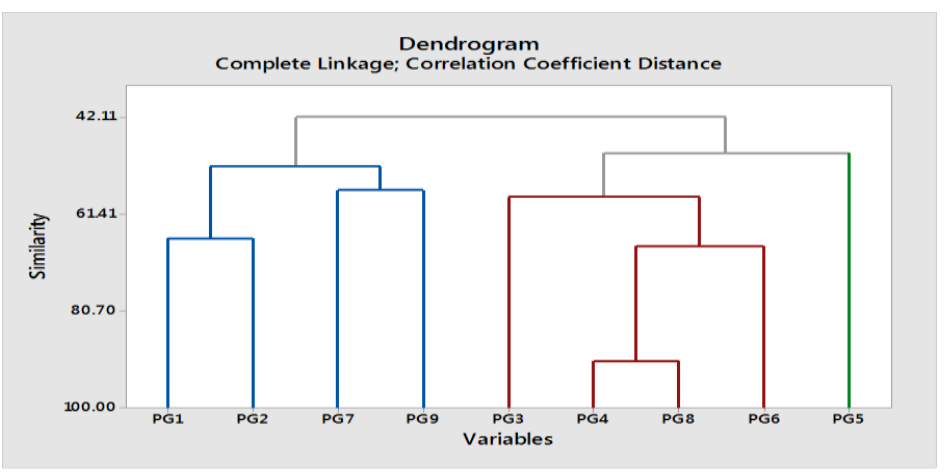

Fig. 8: Represented the Dendgram of similarity (Cluster analysis).

Species abundance was subjected to the cluster analysis (Fig. 8). It detected two groups, stations (PG3, PG4\& PG6) clustered together with about 50\% similarity (Group I) Station PG7 and PG9 with 55\% beside PG1 and PG2 with about 65\% similarity (Group II), The channel station (PG5) did not cluster with other stations.

\section{DISCUSSION}

Syllidae species are sensitive to pollution, such as Streptosyllis aequiseta which considered as dominant species in the study area but disappeared from the station near to the source of drainage, also family Nephtyidae represented by $5 \%$ from the total polychaetes are recorded in the station far away from the source of drainage.

The area of study was dominated by opportunistic species like spionidae sp. such as Prionospio ehlersi, Sabellidae sp. such as Fabricinuda mossambica and Sabella fusca., Sivadas et al. (2010) mentioned that the benthic community in an unstable environment is typically dominated by r-selected species, characterized by higher reproduction rate and genetic variation, and is therefore more stress tolerant such as Spionidae, Cirratulidae, Magelonidae and Cossuridae species, they are surface or subsurface feeders, and are established as pollution indicators (Grassle and Grassle , 1974).

The low diversity in the station near the source of drainage reflects the negative effect of increase organic contaminant. Present results agrees well with the maximum diversity is observed in stations fare away from the source PG9 and PG2, and PG1 
which have moderate values of organic contaminant of oil. The presence of Capitellidae and Cirratulidae species indicated that the area suffer from oil pollution, this agrees with Holmer et al., (1997) and Seo et al., (2014), they mentioned that (Spionid, Cirratulids, Cossurids, Capitellids) are known to have remarkable tolerance of hydrocarbon and other pollutants that are toxic to most other fauna. Further, carnivorous species belonging to the family Glyceridae, Goniadidae, Eunicidae, Nereididae were recorded in low abundance this agree with these results where they share by only $1-2 \%$ from the total polychaetes recorded. Pearson and Rosenberg (1978) reported that Crustaceans, specially the amphipods show high sensitivity to pollution and disappear from highly polluted habitats, so in this study it shared by only $2 \%$ from total fauna and disappeared from all station near the source of oil release.

In general, there was a very low impact of the spills on Polychaetes, but high on amphipod crustaceans and mollusks. This detected by the presence of many empty shells of mollusks recorded during this study. This confirmed by Kalman et al. (2010), who mentioned that biomarkers are generally more sensitive to pollution factors than natural factors.

The general picture of the benthic biota in different stations indicates that the biological diversity coefficient is increased in only two stations (PG2, PG9), which means that they fare away from the source of the pollutants. There is also a relatively high value of the biodiversity factor in PG8 and PG1 stations, which indicates low pollution in these stations. The low values of the biological diversity factor in most other stations can be attributed to the environmental disturbance in the study area and its impact with petroleum organic pollutants and possibly other types of industrial pollutants. the presence of oil residues on the wall of the bottle samples after washing the samples, means that great amount of oil contaminated the area and effect on fauna especially samples of PG4, PG5 and PG6 stations with less number of species and total number of individuals.

The presence of large numbers of foraminifera's shells, as well as dead mollusks and the less number of crustaceans (e.g. Amphipod and Isopoda) give a good evidence of increased negative toxicities of petroleum organic pollutants to benthos in the study area.

\section{REFERENCES}

Abbes, A.; Chouahda, A. and Soltani, N. (2003). Activité comparée de deux biomarqueurs du stress environnemental dans divers tissus chez deux espèces de bivalves pêchées dans la région d'Annaba. Bulletin of Institute of Natural Sciences \& Technology de la Mer, 8 : 123-126.

Amoureux, L.; Rullier, F. and Fishelson, L. (1978). Systématique et Ecologie d'Annélides Polychètes de la presqu'îl du Sinai. Israel Journal of Zoology, 27 (2-3): 57-163.

Ben Eliahu, M. N. (1972). A description of Hydroides steinitzi n. sp. (Polychaeta: Serpulidae) from the Suez Canal with remarks on the serpulid fauna of the canal. Israel Journal of Zoology, 21: 77-81.

Chase, D.A.; Edwards, D.S.; Qin, G.; Wages, M. R.; Willming, M. M.; Anderson T.A.\& Maul, J.D. (2013). Bioaccumulation of petroleum hydrocarbons in fiddler crabs (Uca minax) exposed to weathered MC-252 crude oil alone and in mixture with an oil dispersant. Sciences of the Total Environment, 444: 121127. DOI: $10.1016 /$ j.scitotenv.2012.11.078 
Dargay, J. G. (2010).World Oil Demand's Shift toward Faster Growing and Less Price-Responsive Products and Regions. Energy Policy, 38(10):62616277.http://www.econ.nyu.edu/user/nyarkoy/Oil Demand_DargayGately_Feb2010.pdf

Deshmukh, I. (1986). Ecology and Tropical Biology. Blackwell, USA.

El Komi, M. and Emara, A. (2008). Benthos monitoring in Red Sea, Egypt A- The western coast of the Suez Gulf Egypt. Journal of Aquatic Biology \&Fisheries, Vol. U, (A):57 -79.

El Komi, M. (1996). Coastal development and pollution impacts on the distribution of macrobenthic communities along the eastern coast of the Gulf of Suez (Egypt). Pakistan J. Mari. Sci., 5(1):1-13. http://aquaticcommons.org/17625/1/PJMS5.1_001.pdf

El-Komi, M. M. and Beltagy A. I. (1997). Distribution of macrobenthos assembleges in the north coast of Egypt. Bulletin of National Institute of Oceanography and Fisheries, ARE, 23: 267-293. http://www.niof.sci.eg/images/ejar/vol23/DISTRIBUTION\%20OF\%20MACRO\%20BENTHOS\%20ASSEMBL4GES.pdf

El-Komi, M. M. (1997). Preliminary list to the summer macro benthos in the intertidal zone of the western Gulf of Suez. Bulletin of Institute of Oceanography and Fisheries, 23:295-314.

El-Komi, M.M., Emara, A. M. and Mona, M.H. (2002). Hydrographical and conditions and benthic assemblages in Suez Gulf, Egypt. Pakistan Journal of Marine Scinces, 1:1-18. http://aquaticcommons.org/id/eprint/17803

Fauchald, K. (1977). The polychaete worms. Definitions and keys to the orders, families and genera. Natural History Museum of Los Angeles County, Science Series, 28:188.

Garrity, S.D. and Levings, S.C. (1993). Effects of an oil spill on some organisms living on mangrove (Rhizophora mangle L.) roots in low-wave energy habitats in Caribbean Panama. Marine Environmental Research, 35: 251-271. https://doi.org/10.1016/0141-1136(93)90097-J

Grassle, J. F. and Grassle, J. P. (1974). Opportunistic life histories and genetic system in marine benthic polychaetes. Journal of Marine Reseach, 32: 253-284.

Hargrave, B.T. and Thiel, H. (1983). Assessment of pollution-induced changes in benthic community structure. Marine Pollution Bulletin, 14: 41-46.

Head, I. M.; Jones, D. M. and Röling, W. F. (2006). Marine microorganisms make a meal of oil. National Review Microorganisms, 4(3): 173-182. https://doi.org/10.7287/peerj.preprints.1254v2

Holmer, M.; Forbes, V. E. and Forbes, T. L. (1997). Impact of the polychaete Capitella sp 1 on microbial activity in organicrich marine sediment contaminated with the polycyclic aromatic hydrocarbon fluoranthene. Marine Biology, 128: 679-688.

Kalman, J.; Buffet, P.E. and Amiard, J.C. (2010). Assessment of the influence of confounding factors (weight, salinity) on the response of biomarkers in the estuarine polychaete Nereis diversicolor. Biomarkers, 15:461-469. https://doi.org/10.3109/1354750X.2010.491162

Lucan-Bouché, M. L.; Biagianti-Risbourg, S.; Arsac, F. and Vernet, G. (1999). An original decontamination process developed by aquatic oligochaete Tubifex tubifex exposed to copper and lead. Aquatic Toxicity, 45: 9-17. DOI: 10.1016/S0166-445X(98)00091-5

Massara Paletto, V.; Commendatore, M. G. and Esteves, J.L. (2008). Hydrocarbon levels in sediments and bivalve mollusks from Bahía Nueva (Patagonia, Argentina): an assessment of probable origin and bioaccumulation factors. Marine Pollutant Bulletin, 56(12):2100-2105. DOI: 10.1016/j.marpolbul.2008.08.026 
Musco, L. (2012). Ecology and diversity of Mediterranean hard-bottom Syllidae (Annelida): a community-level approach. Marine Ecology Progress Series, 461:107-119.

Mouneyrac, C.; Perrein-Ettajani, H. and Amiard-Triquet, C. (2010). Influence of anthropogenic stress on fitness and behaviour of a key-species of estuarine ecosystems, the ragworm Nereis diversicolor. Environmental Pollutant, 158:121-128. DOI: 10.1016/j.envpol.2009.07.028

Papageorgioua, N.; Arvanitidisb, C. and Eleftheriou, A. (2006). Multicausal environmental severity: A flexible framework for microtidalsandy beaches and the role of polychaetes as an indicator taxon. Estuarine, Coastal and Shelf . Science, 70:643-653

Pearson, T. H. and Rosenberg, R. (1978). Macrobenthic succession in relation to organic enrichment and pollution of the marinenvironment. Oceanogr. Marine Biological Annual Review, 16 : 229-311.

Por, F. D. (1978). Lessepsian migration. The influx of Red Sea biota into the Mediterranean by way of the Suez Canal. Ecological Studies, 23. SpringerVerlag, Berlin, 228 pp.

Safriel, U. N. and Lipkin Y. (1975). Patterns of colonization of the eastern Mediterranean intertidal zone by Red Sea immigrants. Journal of Ecology, 63:61-63.

Seo, J.Y; Kim, M.; Lim, H. S.; Choi, J. W. (2014). The macrofaunal communities in the shallow subtidal areas for the first 3 years after the Hebei Spirit oil spill. Marine Pollution Bulletin, 82:208-220. https://doi.org/10.1021/es3004156

Sivadas, S.; Ingole, B. and Nanajkar, M. (2010). Benthic polychaetes as good indicators of anthropogenic impact. Indian Journal of Marine Sciences, 39 (2): 201-211. https://www.researchgate.net/publication/45445780

Snelgrove, P.V. (1998). The biodiversity of macrofaunal organism in the marine sediment. Biodivers. Conserv., 7 :1123-1132.

Wiehm, J. L. (1972). Graphic and mathematical analysis of biotic communities in polluted streams. Annual Review, 17: 223-252.

Yu, D.; Yuan, Y.; Jiang, L.; Tai, Y.; Yang, X.; Hu, F. and Xie, Z. (2013). Antiinflammatory effects of essential oil in Echinacea purpurea L. Pakistan journal pharmacy of Science, 26(2):403-408. 